\title{
Creative English Teachers can Make the World a Better Place
}

\author{
Motikala Subba Dewan
}

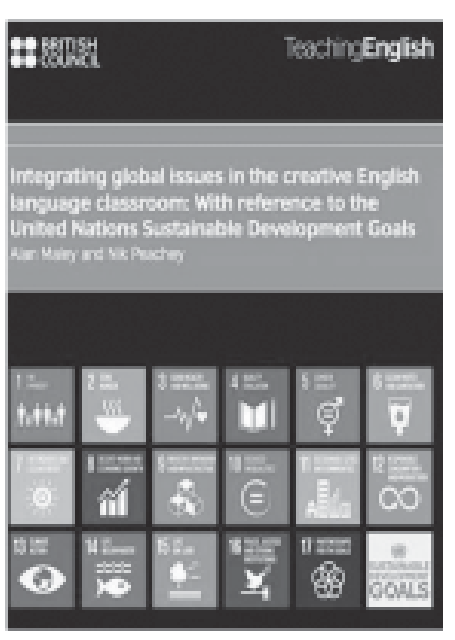

Maley, A. \& Peachey, N. (Ed.). (2017). Integrating global issues in the creative English language classroom: With reference to the United Nations Sustainable Development Goals. London: British Council. (1-203 pages, available online:

https://englishagenda.britishcouncil.org/continuingprofessional-development/teacher-educator-framework/ demonstrating-effective-teaching-behaviour/integratingglobal-issues-creative-english-language-classroom

ISBN 978-0-86355-855-9)
(Reviewer's note - Before I start, I would like to share what made me write this review. Prof. Alan Maley, a famous name in the field of creative writing, requested me in one of his emails whether it is possible to write and publish a review on the book, 'Integrating global issues in the creative English language classroom: With reference to the United Nations Sustainable Development Goals', edited by Alan Maley and Nik Peachey in the journal of NELTA this year. I was in a dilemma; do I write or not? To write a review means to read a whole book first. In the capacity of the president, I was full of responsibilities with the preparation for the $23^{\text {rd }}$ International Conference of NELTA (2018). In addition, it is a very special year as NELTA is celebrating its 25 years, the silver jubilee of NELTA.
Finally, I responded to him positively and requested him to send me the book. Prof. Maley sent me a soft-copy of the book and suggested to get me a hard copy from the British Council (BC) Nepal, which I did. I would like to express sincere thanks to British Council for providing a copy of this book which is not available in the market, though it is available online. Then I tried my luck and started in a snail pace. I went through the book. I found it interesting and very useful for the teachers. Whatever I got insights from the book are sincerely presented below)

English Language Teaching (ELT) today is not just teaching the English language but opening a window to the world through which learners can see and learn many things which are not found in their 'world', 
but which are essential for them to be successful in their life-struggle. The main aim of ELT is undoubtedly to enable learners to communicate with the English speaking people, but with the passing time, its functions have grown into many -from being able to communicate in English to knowing what's happening in the world, from getting a job easily to develop critical thinking, from helping alleviate poverty to connect oneself with the World. It is difficult, almost impossible, to get recognition for one's work, scientific or literary without English. The volume edited by Maley and Peachey is therefore a welcome addition to additional functions of ELT.

As the title of the book suggests, it deals with the United Nations 17 sustainable development goals (SDGs) viz. 1. No Poverty 2. Zero Hunger 3. Good Health and Well-Being 4. Quality Education 5. Gender Equality 6. Clean Water and Sanitation 7. Affordable and Clean Energy 8. Decent Work and Economic Growth 9. Industry Innovation and Infrastructure 10. Reduced Inequalities 11. Sustainable Cities and Communities 12. Responsible Consumption and Production 13. Climate Action 14. Life below Water 15. Life on Land 16. Peace, Justice and Strong Institutions and 17. Partnerships for the Goals. The book contains 22 sections which means that they go beyond the 17 SDGs which have been dealt with in 2-20 sections. The first and the last sections cover the whole range of SDGs, rather than just one. In addition to the fact that the sections introduce SDGs, they do it with creative activities, and try to promote critical thinking.

Each section of the book has a uniform design. They start with 'Introduction' which introduces the reader to the concept of the topic to be taught and other useful information about how to use the activities. Introduction is followed by Activities which are subdivided into aims, language focus, SDG focus (except the first one), creative focus, preparation, and procedure. Some of them have additional ideas such as materials or worksheet, resources and references. This uniformity in format is certainly very helpful to the teachers who wish to use the activities. Under the subheadings, creative focus, the level, the age of the learner and the estimated time for the activity are provided to help teachers. One very good thing about all these sections is that they are not theories and principles related stuffs, instead they are all practical activities which can be used in the classroom. They can easily be adopted and/ or adapted by the teachers to suit their contexts.

The volume is certainly good, however in countries like Nepal, teachers need to be made aware of why they should worry about these UNO SDGs issues rather than 'stick to language teaching' as they 'can't change the world'. In some cases, teachers are often limited with the syllabuses, textbooks and school administration. This is important to let the learners be aware of these important issues along with the prescribed curriculum. The volume maintains to promote creativity, critical thinking and leadership skills. Sometimes, the aims of the activities seem to be broad and their measurability can be questioned. In one section entitled 'Sustainable Goal 2: End Hunger, Achieve Food Security...' (page no 35) in Activity 5, last instruction goes like: Ask another teacher to... which confuses the readers if this is for teaching learners or training teachers. Some sections deal with downloading materials which may not be possible in the majority of schools in Nepal and may be many other parts of the world too. However, a creative teacher can think of the many other choices in their context.

All in all, the volume is worth-reading and useful (adopting/adapting) as all the 
sections are practical to teachers to act. The editors, Alan Maley and Nik Peachey both are well-known names in the ELT community and their experiences are reflected on the pages of the volume. They contain practical activities with clear instructions followed by worksheets wherever necessary. At a personal level, I enjoyed the book which made me think that I am not only an English teacher to teach English language but a 'teacher' to try a bit to help this world a better place. I am sure, English teachers can make a difference once they go through this book and use it appropriately in their own context.

Motikala Subba Dewan is an A/ Professor of English in Tribhuvan University Nepal. Ms. Dewan is the president of Nepal English Language Teachers' Association (NELTA), Central Committee Member of Tribhuvan University Teachers' Association (TUTA), Educational/Legal Consultant of Cosmic Education Training and Research Academy (CETRA), Kathmandu. She is a practicing advocate in the Supreme Court of Nepal. She is a trainer, creative writer, translator, rapporteur and interpreter. She has participated and presented papers in many national and international seminars, workshops and conferences, and conducted trainings and workshops as a consultant in different parts of Nepal. She has published many research articles in different journals and magazines, and published books in both disciplines; English and Law. 